\title{
Effect of harvesting stages and postharvest treatments on shelf life and quality of tomato ( $L y$ - copersicon esculentum Mill. var. Pearson) stored under ZECC condition
}

\author{
Sayed Samiullah Hakimi ${ }^{1,2}$, Neeru Dubey ${ }^{2}$, Yashpal Singh Saharawat ${ }^{3}$ \\ ${ }^{1}$ Department of Horticulture, Faculty of Agriculture, Kabul University, Kabul, Afghanistan \\ ${ }^{2}$ Amity Institute of Horticulture Studies and Research, Amity University Uttar Pradesh, Noida, India \\ ${ }^{3}$ Department of Soil Science and Agriculture Chemistry (SSAC), Department of Soil Science, Indian Agricultural Research Institute, New Delhi, India
}

\section{Special Issue Article \\ Open Access \\ Published}

\section{Keywords}

- Harvesting stages

- Postharvest treatments

- ZECC

- Shelf life

- Postharvest quality

\section{ABSTRACT}

Tomato (Lycopersicon esculentum Mill) is one of the important commercial high value crops of Afghanistan. Among the different local varieties grown in Afghanistan, the "Pearson" variety is most popular because of its good commercial value due to its uniform globe shape and medium to large size. The study is conducted to understand the effects of different harvesting stages and postharvest treatments on the shelf life and postharvest quality of tomatoes (Pearson variety) stored under the Pusa Zero Energy Cool Chamber (ZECC) at the research farm of Agriculture Faculty, Kabul University. This is the first time that ZECC is introduced in Afghanistan for enhancing fruit shelf life. The standard dimension ZECC was built with $165 \times 115 \times 67.6 \mathrm{~cm}$ dimensions. After harvesting tomatoes at different maturity stages (Turning, Pink, and Light red color stages), fruits were precooled, graded, and treated with different concentrations of $\mathrm{CaCl}_{2}$ and mint leaf extract solutions. Thereafter, the tomatoes were placed in plastic baskets and stored in the Zero Energy Cool Chamber. During storage period, Total Soluble Solids (TSS, $0 \mathrm{brix}$ ), $\mathrm{pH}$, firmness ( $\mathrm{gr} \mathrm{cm}^{-2}$ ), shelf life, pericarp thickness (mm), fruit volume (cc), and fruit density were recorded. Two factorial CRD design was considered with harvesting stages as the first factor and postharvest treatments as the second factor. The data revealed that the shelf life of tomatoes was extended up to 29 days under $\mathrm{T}_{2}$ (turning color fruits treated with $6 \% \mathrm{CaCl}_{2}$ ) and followed by $\mathrm{T}_{8}$ (turning color fruits treated with $6 \% \mathrm{CaCl}_{2}+6 \%$ mint Leaves extract) up to 28 days. Under $\mathrm{T}_{2}$, quality parameters such as TSS and pH increased from $3.85 \%$ brix and 2.85 to 4.4 brix and 3.4 , respectively. Firmness, pericarp and volume decreased from $1750 \mathrm{grcm}^{-2}, 0.75 \mathrm{~cm}$ and $135 \mathrm{cc}$ to $840 \mathrm{grcm}^{-}$ $2,0.67 \mathrm{~cm}$ and $127 \mathrm{cc}$, respectively. At the last observation, density remained unchanged (1.00 gr/cc). In conclusion, tomatoes harvested at the turning-color stage treated with $6 \% \mathrm{CaCl}_{2}$ and followed by $6 \% \mathrm{CaCl}_{2}+6 \%$ mint leaves' extract had a significant effect on the enhancement of shelf life and quality of tomatoes under ZECC condition.

Received: January 17, 2020; Revised: March 08, 2020; Accepted: March 08, 2020; Published: June 07, 2020

\section{Introduction}

The tomato (Solanum Lycopersicon Mill) is one of the important commercial crops of Afghanistan. The commercial production of tomatoes is being carried out in the majority of provinces like Paryab, Sarepul, Balkh, Samangan, Baghlan, Kunduz, Takhar, Nangarhar, Laghman, Helmand, Kandahar, Farah, Herat, Kunduz, Mazar- e sharif, Kabul, Parwan, Kapisa, and Logar. In 2018, tomato fields covered 24,892 hectares of land and produced 2,075,222 MT (Agri-Stat Dept, MAIL, 2019). In addition to outdoor cultivation, tomatoes are grown in controlled environments such as greenhouses and plastic tunnels during the offseason in order to increase production and reduce price fluctuations in the country's markets. Historically, the major cultivated varieties in Afghanistan are Roma, Pearson, and Heinz, but more hybrid varieties have recently been grown. The "Pearson" variety is most popular because of its good commercial value, its uniform globe shape, and medium to large size; its taste, flavor, and higher juice and pulp content make it suitable for fresh salads and for processing for sauces. However, Pearson is very sensitive to handling and thus has very short storage life. In fact, harvesting Pearson tomatoes at full red stage has a maximum shelf life about three to six days in Afghanistan [1]. While fresh tomatoes are desired in Afghanistan, dried tomatoes are also used during the off-season as a flavoring agent in food items. Although infrastructure limits distribution of tomato paste and puree, it is available locally among families. In general, farmers face losses of tomato production due to lack of proper postharvest management practices, a low level of knowledge about proper harvesting stages, non-availability of proper postharvest treatments, and the lack of on-farm storage systems to extend the shelf life of fresh tomatoes. As a result, around $40-50 \%$ of tomatoes are wasted. To extend the shelf life of tomatoes and reduce waste, one should determine the proper harvesting stage of tomatoes, standardize postharvest treatments, and provide low-cost on-farm storage systems like ZECC [2].

The present study studies the effect of harvesting stages and postharvest treatments on shelf life and quality of fresh "Pearson" tomatoes stored in ZECC under dry temperate conditions. Tomatoes at pink stage that were dipped at $6 \% \mathrm{CaCl}_{2}$ for 20 minutes maintained their postharvest quality [3]. Mint leaves extract may also be considered due to its antimicrobial [4] and also antifungal 
activities [5]. ZECC is a scientific evaporative cooling system developed at IARI, New Delhi, India [6], which shows a significant effect on enhancing the shelf life of fruits and vegetables. The shelf life of tomato was extended from 7 days in ambient conditions up to 28 days in ZECC $[7,8]$. We investigate ZECC for the first time in Afghanistan to enhance the shelf life of tomatoes.

\section{Methodology}

The study has been conducted at the Research Farm of Agriculture Faculty of Kabul University.

Tomato production: Quality seeds of tomato procured from authorized seed production body and sowed on 9 March 2018 at the farm's nursery. Seeds germinated after 9 days, and seedlings were transplanted to the open field next to the nursery after 38 days. The field was managed properly until the harvesting stage.

Establishment of ZECC: Next to the tomato field, a Zero Energy Cool Chamber (ZECC) with a size of $165 \times 115 \mathrm{x}$ $67.5 \mathrm{~cm}$ was built (Roy \& Khurdiya, 1986). The space between two walls of bricks was maintained at $7.5 \mathrm{~cm}$ and filled with sand. A drip irrigation pipe was placed on top of the sand and connected to a water tank. The bamboo-framed cover woven with straw or grass provided cover for the ZECC. An additional woven mesh and tarpaulin shade were placed above ZECC (Figure 1-3).

Harvesting and management of fruits: Tomatoes were harvested at three different maturity stages after 101 days from transplanting. Fruits were sorted, graded, and precooled (Figure 2).

Experimental details and treatment application: After the initial data had been recorded for all the parameters, tomatoes of all three stages were treated (dipped for 20 minutes) with 24 treatments with two replications under a two-factorial CRD design. The first factor was harvesting stages at three categories (Turning, Pink and Light red color), and the second factor was postharvest treatments at eight levels $\left(0 \%, 6 \% \mathrm{CaCl}_{2}, 2 \%\right.$ mint leaves extract, $4 \%$ mint leaves extract, $6 \%$ mint leaves extract, $6 \% \mathrm{CaCl}_{2}+$ $2 \%$ mint leaves extract, $6 \% \mathrm{CaCl}_{2}+4 \%$ mint leaves extract and $6 \% \mathrm{CaCl}_{2}+6 \%$ mint leaves extract).

Treatment details: $\mathrm{T}_{1}$ (Turning color fruits dipped in distilled water), $\mathrm{T}_{2}$ (Turning color fruits dipped in $6 \%$ $\mathrm{CaCl}_{2}$ solution), $\mathrm{T}_{3}$ (Turning color fruits dipped in $2 \%$ mint leaves' extract solution), $\mathrm{T}_{4}$ (Turning color fruits dipped in $4 \%$ mint leaves' extract solution) $\mathrm{T}_{5}$ (Turning color fruits dipped in $6 \%$ mint leaves' extract solution), $\mathrm{T}_{6}$ (Turning color fruits dipped in $6 \% \mathrm{CaCl}_{2}+2 \%$ mint leaves' extract solution), $\mathrm{T}_{7}$ (Turning color fruits dipped in $6 \% \mathrm{CaCl}_{2}+4 \%$ mint leaves' extract solution), $\mathrm{T}_{8}$ (Turning color fruits dipped in $6 \% \mathrm{CaCl}_{2}+6 \%$ mint leaves' extract solution), $\mathrm{T}_{9}$ (Pink color fruits dipped in distilled water), $\mathrm{T}_{10}$ (Pink color fruits dipped in $6 \% \mathrm{CaCl}_{2}$ solution), $\mathrm{T}_{11}$ (Pink color fruits dipped in $2 \%$ mint leaves' extract solution), $\mathrm{T}_{12}$ (Pink color fruits dipped in $4 \%$ mint leaves' extract solution) $\mathrm{T}_{13}$ (Pink color fruits dipped in $6 \%$ mint leaves' extract solution),
$\mathrm{T}_{14}$ (Pink color fruits dipped in $6 \% \mathrm{CaCl}_{2}+2 \%$ mint leaves' extract solution), $\mathrm{T}_{15}$ (Pink color fruits dipped in $6 \% \mathrm{CaCl}_{2}$ $+4 \%$ mint leaves' extract solution), $\mathrm{T}_{16}$ (Pink color fruits dipped in $6 \% \mathrm{CaCl}_{2}+6 \%$ mint leaves' extract solution), $\mathrm{T}_{17}$ (Light red color fruits dipped in distilled water), $\mathrm{T}_{18}$ (Light red color fruits dipped in $6 \% \mathrm{CaCl}_{2}$ solution), $\mathrm{T}_{19}$ (Light red color fruits dipped in 2\% mint leaves' extract solution), $\mathrm{T}_{20}$ (Light red color fruits dipped in 4\% mint leaves' extract solution) $\mathrm{T}_{21}$ (Light red color fruits dipped in $6 \%$ mint leaves' extract solution), $\mathrm{T}_{22}$ (Light red color fruits dipped in $6 \% \mathrm{CaCl}_{2}+2 \%$ mint leaves' extract solution), $\mathrm{T}_{23}$ (Light red color fruits dipped in $6 \% \mathrm{CaCl}_{2}+$ $4 \%$ mint leaves' extract solution), $\mathrm{T}_{24}$ (Light red color fruits dipped in $6 \% \mathrm{CaCl}_{2}+6 \%$ mint leaves' extract solution). The mint leaves were processed with a juicer machine to extract water without adding any chemical or organic reagents; $12 \mathrm{~kg}$ of mint extracts 1 liter of water. After treatment application, $500 \mathrm{gr}$ fruits from each experimental treatment were put in plastic trays and subjected to storage under ZECC condition.

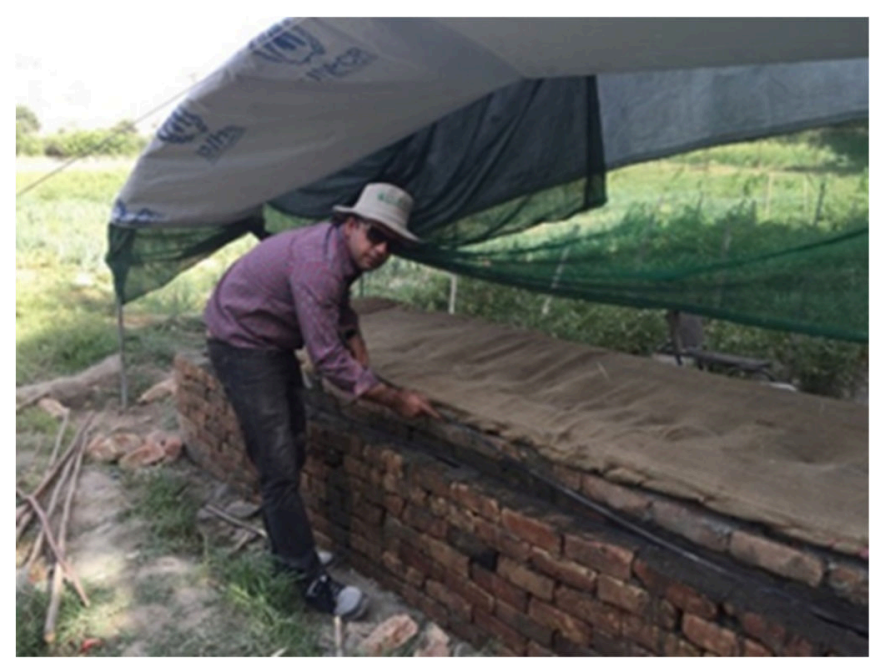

Figure 1. ZECC construction.

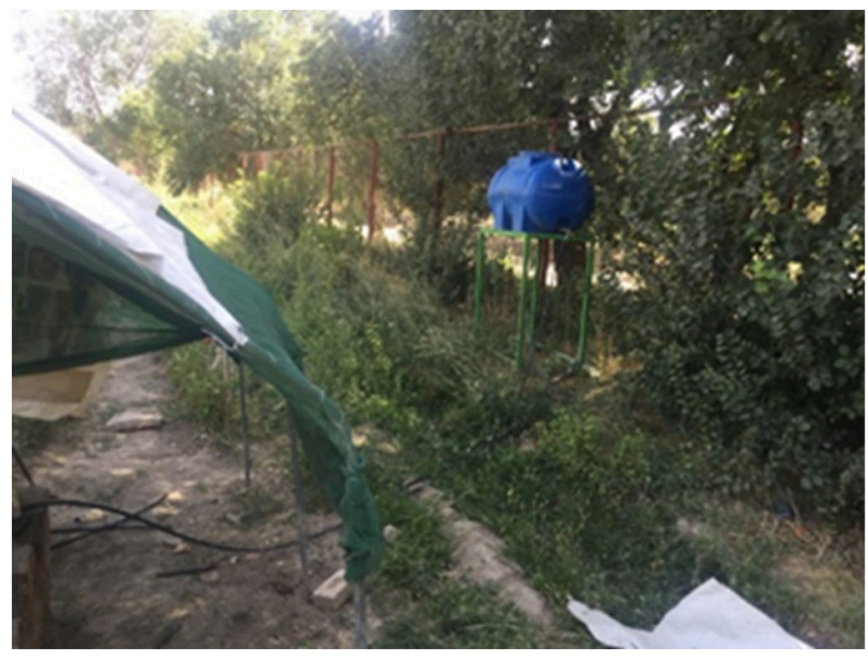

Figure 2. ZECC construction and related water tank.

Data recording and analysis: While the shelf life of tomatoes were observed daily, quality parameters were 
recorded at ten-day intervals for the fruits' firmness $\left(\mathrm{grcm}^{-2}\right)$, pericarp thickness ( $\mathrm{cm}$ or $\mathrm{mm}$ ), volume (cc), density (gr/cc), $\mathrm{pH}$ and TSS ( $\left.{ }^{\circ} \mathrm{brix}\right)$. The data were analyzed through a statistical analysis program (Excel) to analyze ANOVA and considered LSD at 5\% level of significance.

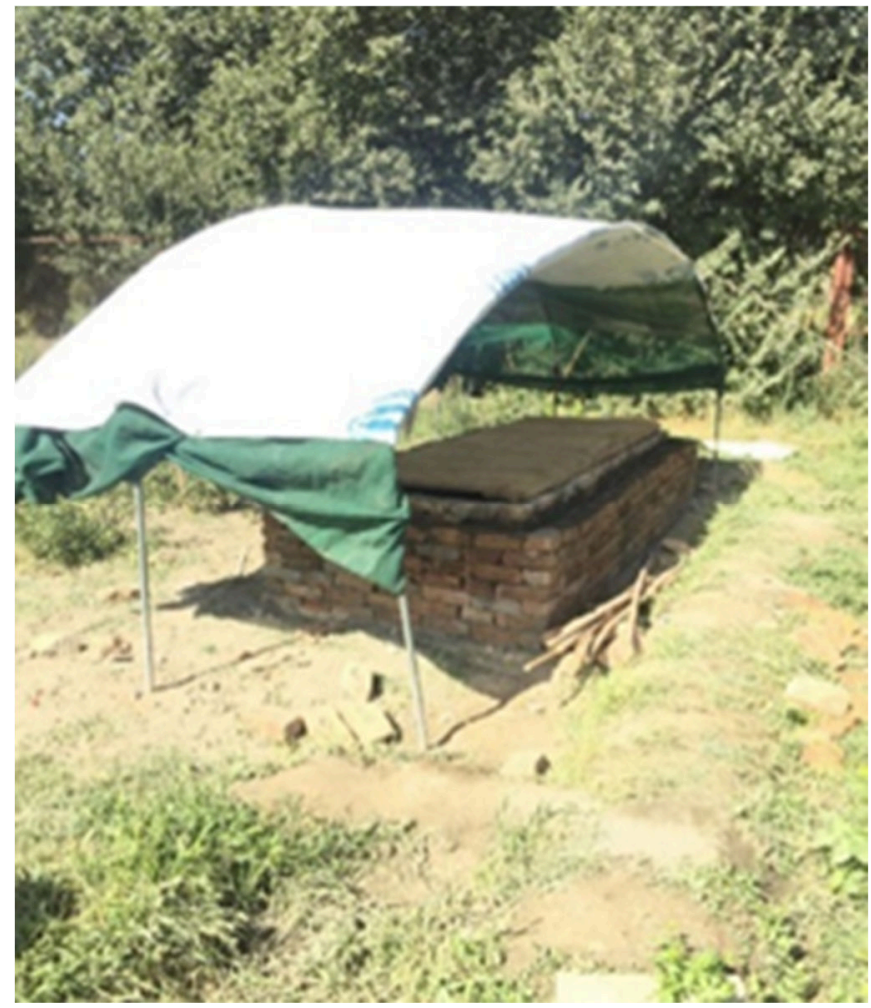

Figure 3. ZECC construction and related water tank completed.

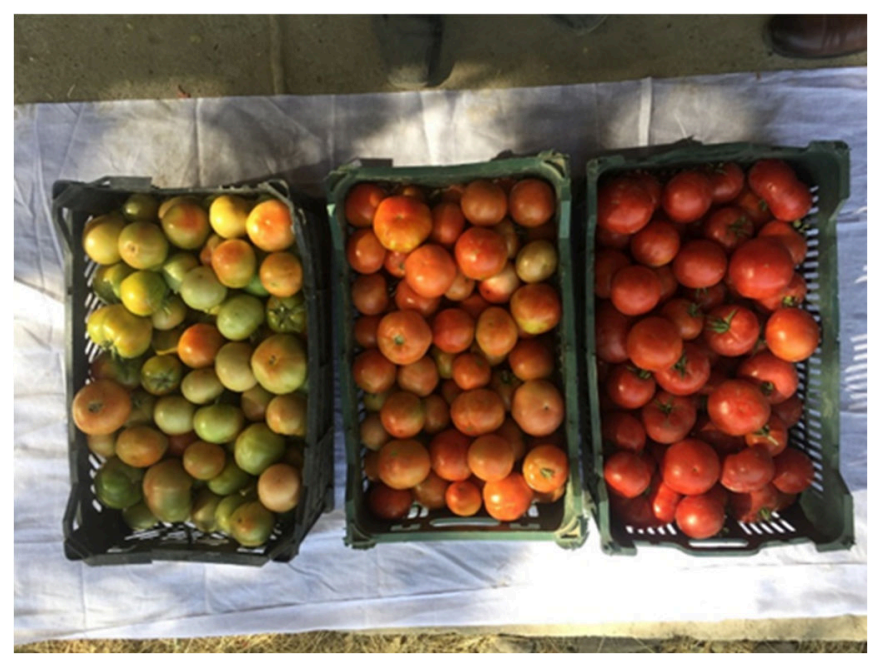

Figure 4. Three categories of tomato's fruits.

\section{Results and Discussion}

The evaporative cooling system (Zero Energy Cool Chamber) is an extremely innovative, low-cost farm storage system solution. It reduces the average temperature from 30 to $12^{\circ} \mathrm{C}$ and increased the average relative humidity from 25 to $95 \%$ during one month of storage. The low cost onfarm storage (ZECC) is not only effective for extending tomato shelf life but also the shelf lives of other vegetables and fruits in Afghanistan. Because of the nation's dry temperate climate, suitable wind could further increase the efficiency of ZECC. The best treatment $\mathrm{T}_{2}$ (harvesting of turning color fruits dipped in $6 \% \mathrm{CaCl}_{2}$ solution) under ZECC condition increased the shelf life up to 29 days compared to 17 days under ambient conditions on our farm or just 3 to 6 days shelf life under ambient conditions in the literature [1]. This agrees with the ZECC results reported by Islam et al. [8], and Esa Abiso et al. [9], also reported that ZECC had a significant effect on tomato shelf life and postharvest quality compared to ambient storage conditions. Furthermore, the results on shelf life and other parameters of Pearson tomatoes are discussed below.

\subsection{Shelf life}

Under ZECC conditions, harvesting stages and postharvest treatments enhanced the tomatoes' shelf life. Treatment $\mathrm{T}_{2}$ (Turning color fruits dipped in $6 \% \mathrm{CaCl}_{2}$ solution) increased the shelf life up to 29 days (Figure 3). Based on LSD analysis, treatment $\mathrm{T}_{8}$ (Turning color fruits dipped in $6 \% \mathrm{CaCl}_{2}+6 \%$ mint leaves' extract solution) is on par with $\mathrm{T}_{2}$ and extended the shelf life of tomatoes up to 28 days. Four treatments $\mathrm{T}_{11}$ (pink color fruits dipped in 2\% mint leaves' extract solution), $\mathrm{T}_{17}$ (light red color fruits dipped in distilled water), $\mathrm{T}_{20}$ ( Light red color fruits dipped in $4 \%$ mint leaves' extract solution) and $\mathrm{T}_{21}$ (Light red color fruits dipped in 6\% mint leaves' extract solution) had the same lowest shelf life of about 20 days. The results show that the combined effect of both factors (harvesting of turning color fruits and application of $6 \% \mathrm{CaCl}_{2}$ solution) as in $\mathrm{T}_{2}$ was significantly different from other treatments presented in Table 1. The difference might be due to harvesting tomatoes at earlier maturity stages to maintain the fruits' quality and enhance shelf life, similar to results from studies in [10-13]. Fruits at earlier stages (turning color) could have longer shelf life due to low physiological activity compared to later stages under ZECC condition. The antifungal application maintains firmness through $6 \% \mathrm{CaCl}_{2}$, saving its quality attributes and further enhancing shelf life, similar to reports by Arthur et al. and Chepngeno et al. $[3,14]$. 


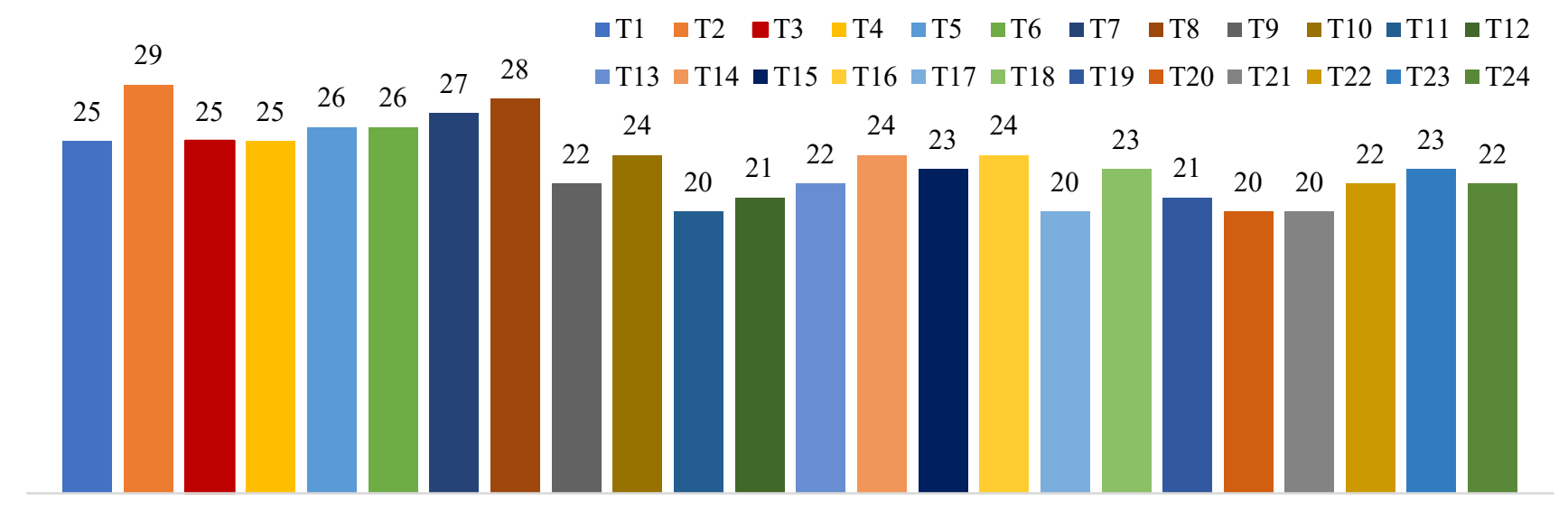

Shelf life (Number of days)

Figure 5. The shelf life of marketable fruits affected through combined treatments (Harvesting stages and postharvest treatments) stored in ZECC storage system provided an average $12{ }^{\circ} \mathrm{C}$ temperature and $95 \%$ relative humidity.

Table 1: The LSD analysis of shelf life among treatments presented at $5 \%$ level of signifcance.

\begin{tabular}{|c|c|c|}
\hline Trt. No. & Treatments' details & Shelf life (Number of storage days) \\
\hline T1 & Turning color fruits dipped in distilled water & $25^{\text {cdef }}$ \\
\hline $\mathrm{T} 2$ & Turning color fruits dipped in $6 \% \mathrm{CaCl}_{2}$ solution & $\underline{29 a}$ \\
\hline T3 & Turning color fruits dipped in $2 \%$ mint leaves' extract solution & $25^{\text {cdefg }}$ \\
\hline $\mathrm{T} 4$ & Turning color fruits dipped in $4 \%$ mint leaves' extract solution & $25^{\text {cdefgh }}$ \\
\hline T5 & Turning color fruits dipped in $6 \%$ mint leaves' extract solution & $26^{\mathrm{bcd}}$ \\
\hline T6 & Turning color fruits dipped in $6 \% \mathrm{CaCl}_{2}+2 \%$ mint leaves' extract solution & $26^{\text {bcde }}$ \\
\hline $\mathrm{T} 7$ & Turning color fruits dipped in $6 \% \mathrm{CaCl}_{2}+4 \%$ mint leaves' extract solution & $27 \mathrm{abc}$ \\
\hline T8 & Turning color fruits dipped in $6 \% \mathrm{CaCl}_{2}+6 \%$ mint leaves' extract solution & $28^{\mathrm{ab}}$ \\
\hline T9 & Pink color fruits dipped in distilled water & 22 ijklmno \\
\hline $\mathrm{T} 10$ & Pink color fruits dipped in $6 \% \mathrm{CaCl}_{2}$ solution & 24 cdefghi \\
\hline $\mathrm{T} 11$ & Pink color fruits dipped in $2 \%$ mint leaves' extract solution & 20 op \\
\hline $\mathrm{T} 12$ & Pink color fruits dipped in $4 \%$ mint leaves' extract solution & $21^{\text {lmnop }}$ \\
\hline $\mathrm{T} 13$ & Pink color fruits dipped in $6 \%$ mint leaves' extract solution & 22 ijklmnop \\
\hline T14 & Pink color fruits dipped in $6 \% \mathrm{CaCl}_{2}+2 \%$ mint leaves' extract solution & 24 defghij \\
\hline $\mathrm{T} 15$ & Pink color fruits dipped in $6 \% \mathrm{CaC}_{12}+4 \%$ mint leaves' extract solution & 23 fghijkl \\
\hline $\mathrm{T} 16$ & Pink color fruits dipped in $6 \% \mathrm{CaCl}_{2}+6 \%$ mint leaves' extract solution & 24 defghijk \\
\hline $\mathrm{T} 17$ & Light red color fruits dipped in distilled water & 20 op \\
\hline $\mathrm{T} 18$ & ight red color fruits dipped in $6 \% \mathrm{CaCl}_{2}$ solution & 23 fghijklm \\
\hline T19 & Light red color fruits dipped in $2 \%$ mint leaves' extract solution & 21 lmnop \\
\hline $\mathrm{T} 20$ & Light red color fruits dipped in $4 \%$ mint leaves' extract solution & 20 op \\
\hline $\mathrm{T} 21$ & Light red color fruits dipped in 6\% mint leaves' extract solution & 20 op \\
\hline $\mathrm{T} 22$ & Light red color fruits dipped in $6 \% \mathrm{CaCl}_{2}+2 \%$ mint leaves' extract solution & 22 ijklmnop \\
\hline $\mathrm{T} 23$ & Light red color fruits dipped in $6 \% \mathrm{CaCl}_{2}+4 \%$ mint leaves' extract solution & 23 fghijklmn \\
\hline \multirow[t]{2}{*}{$\mathrm{T} 24$} & Light red color fruits dipped in $6 \% \mathrm{CaCl}_{2}+6 \%$ mint leaves' extract solution & 22 ijklmnop \\
\hline & F-test & $* *$ \\
\hline
\end{tabular}

** (Highly significant level at $1 \%$ )

\section{Total Soluble Solid (TSS ${ }^{0}$ Brix)}

TSS increased up to 20 days of storage for all the treatments. While there were no significant differences among treatments, the lowest changes of TSS were 4.25 and $4.40{ }^{\circ} \mathrm{Brix}$, under treatment $\mathrm{T}_{2}$ (Turning color fruits dipped in $6 \% \mathrm{CaCl}_{2}$ solution) on the $10^{\text {th }}$ and $20^{\text {th }}$ day of storage, respectively (Table 2). The combination of harvesting stages and postharvest treatments did not significantly affect TSS, in agreement with results from Senevirathna \& Daundasekera [15]. But maintaining tomatoes to small TSS changes under $\mathrm{T}_{2}$ could be explained by being slightly physiologically active at the color-turning stage and the $6 \% \mathrm{CaCl}_{2}$ application, agreeing with the report from [3]. 


\section{5. pH of tomatoes}

Differences of $\mathrm{pH}$ were also not significant among treatments. As shown in Figure 2, pH increased during the storage period. The smallest changes were observed under $\mathrm{T}_{2}$ (Turning color fruits dipped in $6 \% \mathrm{CaCl}_{2}$ solution) recorded on the $10^{\text {th }}$ and $20^{\text {th }}$ days of storage as 3.25 and 3.40 , respectively. We conclude that the combination of harvesting stages and postharvest treatments did not significantly affect the $\mathrm{pH}$. These results on tomato $\mathrm{pH}$ agree with results from Senevirathna \& Daundasekera [15] and Casierra [10]. The small $\mathrm{pH}$ changes under $\mathrm{T}_{2}$ might be due to slow physiological activity during the turning-color phase and the $6 \% \mathrm{CaCl}_{2}$ application, similar to results by [3].

Table 2: Table 2: The LSD analysis of fruits firmness at $5 \%$ level and also presenting the significance level of TSS ( $\left.{ }^{\circ} \mathrm{Brix}\right)$ and $\mathrm{pH}$ of stored fruits under ZECC system.

\begin{tabular}{|c|c|c|c|c|c|c|c|c|c|}
\hline \multirow[b]{2}{*}{ Trt. No. } & \multicolumn{3}{|c|}{ TSS ( ${ }^{0}$ brix) } & \multicolumn{3}{|l|}{$\mathrm{pH}$} & \multicolumn{3}{|c|}{ Frimnes gr $\mathrm{cm}^{-2}$} \\
\hline & Initial & 10th day & 20th day & Initial & 10th day & 20th day & Initial & $\begin{array}{l}10^{\text {th }} \\
\text { day }\end{array}$ & $20^{\text {th }}$ day \\
\hline $\mathrm{T} 1$ & 3.85 & 5.00 & 5.50 & 2.85 & 3.45 & 3.60 & 1750 & $900^{\mathrm{bc}}$ & 775 abcdef \\
\hline $\mathrm{T} 2$ & 3.85 & 4.25 & 4.40 & 2.85 & 3.25 & 3.40 & 1750 & $1123^{a}$ & $840^{a}$ \\
\hline T3 & 3.85 & 4.75 & 4.80 & 2.85 & 3.35 & 3.50 & 1750 & 850 & $800 a b c$ \\
\hline $\mathrm{T} 4$ & 3.85 & 4.50 & 4.90 & 2.85 & 3.65 & 3.55 & 1750 & $900^{\mathrm{bcd}}$ & 775 abcdefg \\
\hline $\mathrm{T} 5$ & 3.85 & 4.65 & 5.30 & 2.85 & 3.45 & 3.40 & 1750 & $650 \mathrm{ijklm}$ & 598 abcdefgijklm \\
\hline T6 & 3.85 & 4.40 & 4.75 & 2.85 & 3.45 & 3.45 & 1750 & 750 cdefgij & 710 abcdefgij \\
\hline $\mathrm{T} 7$ & 3.85 & 4.75 & 5.25 & 2.85 & 3.45 & 3.45 & 1750 & $900^{\text {bcde }}$ & 800 abcd \\
\hline T8 & 3.85 & 4.50 & 5.00 & 2.85 & 3.35 & 3.40 & 1750 & $975^{\mathrm{ab}}$ & $825 \mathrm{ab}$ \\
\hline T9 & 4.25 & 5.50 & 5.75 & 2.95 & 3.60 & 3.60 & 950 & 590 jklm & $450 \mathrm{jklm}$ \\
\hline $\mathrm{T} 10$ & 4.25 & 4.35 & 4.75 & 2.95 & 3.25 & 3.50 & 950 & 900 bcdef & 775 abcdefgh \\
\hline $\mathrm{T} 11$ & 4.25 & 4.90 & 5.00 & 2.95 & 3.35 & 3.90 & 950 & 750 cdefgijk & 550 cdefgijklm \\
\hline $\mathrm{T} 12$ & 4.25 & 5.25 & 4.75 & 2.95 & 3.65 & 3.80 & 950 & $625^{\mathrm{ijklm}}$ & 610 abcdefgijklm \\
\hline $\mathrm{T} 13$ & 4.25 & 4.75 & 5.25 & 2.95 & 3.65 & 3.50 & 950 & 700 gijklm & $495 \mathrm{ijklm}$ \\
\hline $\mathrm{T} 14$ & 4.25 & 4.85 & 5.20 & 2.95 & 3.55 & 3.55 & 950 & 880 bcdefg & 710 abcdefgijk \\
\hline $\mathrm{T} 15$ & 4.25 & 5.10 & 5.10 & 2.95 & 3.30 & 3.55 & 950 & 790 bcdefghi & 785 abcde \\
\hline $\mathrm{T} 16$ & 4.25 & 4.75 & 4.75 & 2.95 & 3.45 & 3.60 & 950 & 750 cdefghijkl & 725 abcdefgi \\
\hline $\mathrm{T} 17$ & 4.50 & 5.15 & 6.00 & 3.25 & 3.40 & 4.10 & 750 & $538^{m}$ & $400 \mathrm{~lm}$ \\
\hline $\mathrm{T} 18$ & 4.50 & 4.50 & 4.75 & 3.25 & 3.45 & 3.50 & 750 & 725 cdefghijklm & 660 abcdefgijkl \\
\hline $\mathrm{T} 19$ & 4.50 & 4.75 & 5.50 & 3.25 & 3.65 & 4.00 & 750 & 675 hijklm & $500 \mathrm{ijklm}$ \\
\hline $\mathrm{T} 20$ & 4.50 & 5.10 & 5.50 & 3.25 & 3.75 & 3.80 & 750 & 580 jklm & $400^{\mathrm{lm}}$ \\
\hline $\mathrm{T} 21$ & 4.50 & 5.25 & 4.75 & 3.25 & 3.70 & 3.85 & 750 & $550^{\mathrm{m}}$ & 550 cdefgijklm \\
\hline $\mathrm{T} 22$ & 4.50 & 4.75 & 5.65 & 3.25 & 3.30 & 4.00 & 750 & $600 \mathrm{ijklm}$ & 545 cdefgijklm \\
\hline $\mathrm{T} 23$ & 4.50 & 5.50 & 5.25 & 3.25 & 3.40 & 3.70 & 750 & 700 ghijklm & 625 abcdefgijklm \\
\hline $\mathrm{T} 24$ & 4.50 & 4.75 & 5.00 & 3.25 & 3.40 & 4.00 & 750 & 700 ghijklm & 625 abcdefgijklm \\
\hline F-Test & & NS & NS & - & NS & NS & - & $*$ & $*$ \\
\hline
\end{tabular}

NS (Non-Significant), * (Significance level at 5\%)

\section{Firmness $\left(\mathrm{gr} \mathrm{cm}^{-2}\right)$}

Figure 4 shows the effect of harvesting stages and postharvest treatments on tomato firmness under ZECC. Generally, the firmness of fruits decreased during the storage period, but there was significant difference in maintaining the highest firmness among treatments. The highest firmness was observed for $\mathrm{T}_{2}$ (Turning color fruits dipped in $6 \% \mathrm{CaCl}_{2}$ solution) as 1123 and $840 \mathrm{grcm}^{-2}$ on $10^{\text {th }}$ and $20^{\text {th }}$ days of storage, respectively. Treatment $T_{8}$ is comparable to $\mathrm{T}_{2}$ on the $10^{\text {th }}$ day of storage as shown on Table 2. Tomatoes remained more firm due to the application of $6 \% \mathrm{CaCl}_{2}$, similar to results from Senevirathna et al. [15], Pinheiro et al. [16], and Casierra [10]. Harvesting at early stages (turning color stage) might have significant effect on maintaining fruits' firmness, in agreement with Parkar \& Maleekuu [13], Wu et al. [17], and Moneruzzaman et al. [18]. Retaining firmness may also be attributed to both factors of harvesting stages and $\mathrm{CaCl}_{2}$ in agreement with Islam et al. [7]. 


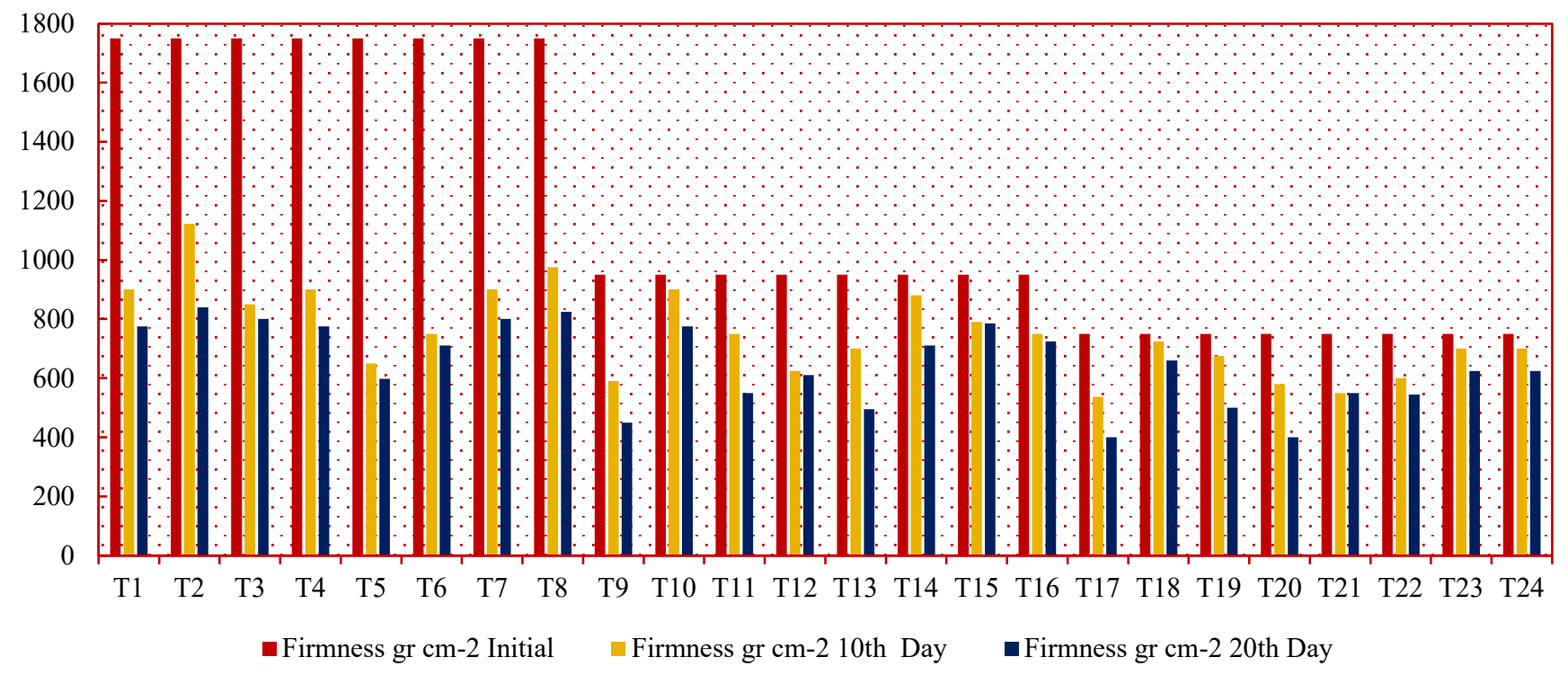

Figure 6. The differences of fruits' firmness affected (grcm-2) through harvesting stages and postharvest treatments stored in ZECC.

\section{Volume (cc) and Density (gr/cc)}

Table 3 shows that the volume of tomato fruits generally decreased during storage period. All the treatments did not have significant differences with respect to decreasing volume, but the smallest changes of volume were reported as 132.5 and $127 \mathrm{cc}$ recorded under $\mathrm{T}_{2}$ (Turning color fruits dipped in $6 \% \mathrm{CaCl}_{2}$ solution) on $10^{\text {th }}$ and $20^{\text {th }}$ day of storage, respectively. Small changes of volume might be due to high firmness and followed by smaller losses of weight of turning-color tomatoes with $6 \% \mathrm{CaCl}_{2}$ application under ZECC conditions. Furthermore, the density of fruits under all treatments did not change.

\section{Pericarp thickness ( $\mathrm{cm}$ or $\mathrm{mm}$ )}

Pericarp thickness of tomatoes became thinner during storage time (Table 3). There was no significant difference regarding pericarp thickness among treatments, but the highest thickness of pericarp was recorded under $\mathrm{T}_{2}$ (Turning color fruits dipped in $6 \% \mathrm{CaCl}_{2}$ solution) as 0.75 and $0.67 \mathrm{~cm}$ on $10^{\text {th }}$ and $20^{\text {th }}$ day of storage, respectively. The thickness of pericarp may be due to the harvesting tomatoes at an early stage, similar to results from Parkar \& Maleekuu [13]. $6 \% \mathrm{CaCl}_{2}$ application might also have affect pericarp thickness by maintaining firmness under ZECC storage, similar to results from Pinheiro et al. [16].

Table 3: Data recorded on volume, density and pericarp thickness of tomato stored under ZECC.

\begin{tabular}{llllllllll}
\hline \multirow{2}{*}{ Trt. No. } & \multicolumn{3}{l}{ Volume $(\mathrm{cc})$} & \multicolumn{3}{l}{ Density $(\mathrm{gr} / \mathrm{cc})$} \\
\cline { 2 - 9 } & Initial & $10^{\text {th }}$ Day & $20^{\text {th }}$ day & Initial & $10^{\text {th }}$ Day & $20^{\text {th }}$ day & Initial & $10^{\text {th }}$ Day & $20^{\text {th }}$ day \\
\hline T1 & 135 & 121.5 & 120.0 & 1.00 & 1.05 & 0.99 & 0.75 & 0.65 & 0.55 \\
T2 & 135 & $\underline{132.5}$ & $\underline{127.0}$ & 1.00 & 1.00 & 1.00 & 0.75 & $\underline{0.75}$ & $\underline{0.67}$ \\
T3 & 135 & 127.5 & 117.5 & 1.00 & 1.00 & 1.02 & 0.75 & 0.65 & 0.55 \\
T4 & 135 & 120.0 & 120.0 & 1.00 & 1.00 & 0.99 & 0.75 & 0.70 & 0.50 \\
T5 & 135 & 125.0 & 120.0 & 1.00 & 0.98 & 1.00 & 0.75 & 0.70 & 0.55 \\
T6 & 135 & 129.0 & 120.0 & 1.00 & 0.99 & 1.01 & 0.75 & 0.70 & 0.55 \\
T7 & 135 & 130.0 & 125.0 & 1.00 & 1.01 & 1.01 & 0.75 & 0.75 & 0.65 \\
T8 & 135 & 130.0 & 125.0 & 1.00 & 0.98 & 1.01 & 0.75 & 0.70 & 0.60 \\
T9 & 135 & 121.5 & 117.5 & 1.00 & 1.01 & 1.00 & 0.75 & 0.65 & 0.55 \\
T10 & 135 & 131.0 & 125.0 & 1.00 & 1.01 & 0.98 & 0.75 & 0.68 & 0.65 \\
T11 & 135 & 127.5 & 117.5 & 1.00 & 0.99 & 0.99 & 0.75 & 0.60 & 0.45 \\
T12 & 135 & 124.5 & 115.0 & 1.00 & 1.00 & 1.01 & 0.75 & 0.55 & 0.45 \\
T13 & 135 & 128.0 & 115.0 & 1.00 & 1.01 & 0.99 & 0.75 & 0.65 & 0.58 \\
T14 & 135 & 120.0 & 120.0 & 1.00 & 0.99 & 1.00 & 0.75 & 0.65 & 0.60 \\
T15 & 135 & 127.5 & 121.0 & 1.00 & 1.05 & 0.98 & 0.75 & 0.68 & 0.55
\end{tabular}




\begin{tabular}{llllllllll} 
T16 & 135 & 129.5 & 122.5 & 1.00 & 0.99 & 1.00 & 0.75 & 0.65 & 0.60 \\
T17 & 134 & 121.0 & 115.0 & 1.00 & 1.01 & 0.97 & 0.65 & 0.55 & 0.45 \\
T18 & 134 & 130.0 & 125.5 & 1.00 & 1.00 & 0.96 & 0.65 & 0.65 & 0.60 \\
T19 & 134 & 122.5 & 120.0 & 1.00 & 1.00 & 0.99 & 0.65 & 0.60 & 0.45 \\
T20 & 134 & 119.0 & 117.5 & 1.00 & 0.97 & 0.99 & 0.65 & 0.50 & 0.45 \\
T21 & 134 & 127.5 & 117.5 & 1.00 & 1.00 & 1.02 & 0.65 & 0.58 & 0.55 \\
T22 & 134 & 120.0 & 120.0 & 1.00 & 0.99 & 1.00 & 0.65 & 0.55 & 0.55 \\
T23 & 134 & 125.0 & 123.0 & 1.00 & 1.01 & 0.95 & 0.65 & 0.55 & 0.55 \\
T24 & 134 & 130.0 & 120.0 & 1.00 & 1.02 & 0.97 & 0.65 & 0.63 & 0.60 \\
F-Test & NS & NS & - & NS & NS & - & NS & NS \\
\hline NS (Not significant) & &
\end{tabular}

\section{Conclusion}

This study identifies factors that significantly influence the shelf life and quality of Pearson tomatoes in Afghanistan stored with the innovative ZECC system. ZECC extended the shelf life of turning-color Pearson tomatoes up to 29 days of storage with $6 \% \mathrm{CaCl}_{2}$ treatment and 25 days of storage without. ZECC enhanced the shelf life of pink color tomatoes up to 24 days with $6 \% \mathrm{CaCl}_{2}$ treatment and 20 days without. Light red stage shelf life was increased up to 23 days treated with $6 \% \mathrm{CaCl}_{2}$ and 20 days without. In comparison, Pearson tomatoes in Afghanistan harvested at full red color stage has a maximum of 6 days storage under ambient conditions. Harvesting stages and postharvest treatment $\left(6 \% \mathrm{CaCl}_{2}\right)$ had significant effects on fruit firmness and shelf life. Postharvest treatments $6 \%$ $\mathrm{CaCl}_{2}$ and $6 \% \mathrm{CaCl}_{2}+6 \%$ mint leaf extract solution had little difference in fruit quality. In conclusion, it is best to harvest Pearson tomatoes at the turning-color stage, which were 5 and 6 days more storage resiliency compared to harvested pink color and light red color tomatoes, respectively. ZECC storage could be the best option for farm storage for small-scale farmers of tomatoes and other important crops in Afghanistan. $\mathrm{A} \mathrm{CaCl}_{2}$ of $6 \%$ concentration postharvest treatment maintains tomato firmness and increases shelf life. Mint leaf extract did not show significant effect on quality or shelf life, possibly due to its low concentration.

\section{References}

[1] Agriculture Statistic Department (2017) Ministry of Agriculture, Irrigation and Livestock (https://www.mail.gov.af/ en) Accessed: 1 November 2019

[2] Saraswathy S, Preethi TL, Balasubramanyan S, Suresh J, Revathy $\mathrm{N}$, et al. (2008) "Postharvest management of horticultural crops," 1st ed. Rajasthan, India, Agrobios (India). 577 p. ISBN: 978-81-7754-322-3

[3] Arthur E, Oduro I, Kumah P (2015) "Postharvest Quality Response of Tomato (Lycopersicon Esculentum, Mill) Fruits to Different Concentrations of Calcium Chloride at
Different Dip- Times" American Journal of Food and Nutrition (pp. 1-8)

[4] Al-Sum BA, Al-Arfaj AA (2014) "Antimicrobial Activity of the Aqueous Extract of Mint Plant" Science Journal of Clinical Medicine (vol. 2, no. 3, pp. 110) https://doi.org/ 10.11648/j.sjcm.20130203.19

[5] Moghaddam M, Pourbaige M, Tabar HK, Farhadi N, Hosseini SMA (2013) "Composition and Antifungal Activity of Peppermint (Mentha piperita) Essential Oil from Iran" Journal of Essential Oil Bearing Plants (vol. 16, no. 4, pp. 506-512) https://doi.org/10.1080/0972060X.2013.813265

[6] A LB, Dv S, V B (2011) "Evaporative cooling system for storage of fruits and vegetables - a review." J Food Sci Technol (vol. 50, no. 3, pp. 429-442) https://doi.org/10.1007/ s13197-011-0311-6

[7] Islam MP, Morimoto T, Hatou K (2012) "Storage behavior of tomato inside a zero energy cool chamber" Agricultural Engineering International: CIGR Journal (vol. 14, no. 4, pp. 209-217)

[8] Islam MP, Morimoto T (2012) "Zero Energy Cool Chamber for Extending the Shelf-Life of Tomato and Eggplant" Japan Agricultural Research Quarterly: JARQ (vol. 46, no. 3, pp. 257-267) https://doi.org/10.6090/jarq.46.257

[9] Abiso E, Satheesh N, Hailu A (2015) "Effect of storage methods and ripening stages on postharvest quality of tomato (Lycopersicom esculentum Mill) cv. Chali" Annals. Food Science and Technology 2015 Targoviste, Romania, Valahia University Press, vol. 16 - pp. 127-137. (https://pdfs.sematicscholar.org/9809/8738e65c315b8a4efc4c4adede4d821 448ac.pdf?_ga=2.219181342.643294641.1587536878321628801.1585267670) Accessed: 1 November 2019

[10] Casierra-Posada F, Aguilar-Avendaño ÓE (2008) "Quality of tomato fruits (Solanum lycopersicum L.) harvested at different maturity stages" Agronomía Colombiana (vol. 26, no. 2, pp. 300-307)

[11] Dhall RK, Singh P (2013) "Effect of Ethephon and Ethylene Gas on Ripening and Quality of Tomato (Solanum Lycopersicum L.) during Cold Storage" Journal of Nutrition \& Food Sciences (vol. 3, no. 6, pp. 1-7) https://doi.org/10.4172/ 2155-9600.1000244 
[12] Dumas Y, Dadomo M, Lucca GD, Grolier P (2003) “Effects of environmental factors and agricultural techniques on antioxidantcontent of tomatoes" Journal of the Science of Food and Agriculture (vol. 83, no. 5, pp. 369-382) https://doi.org/10.1002/jsfa.1370

[13] Parker R, Maalekuu B (2013) "The effect of harvesting stage on fruit quality and shelf-life of four tomato cultivars (Lycopersicon esculentum Mill)" Agriculture and Biology Journal of North America (vol. 4, no. 3, pp. 252-259) https://doi.org/10.5251/abjna.2013.4.3.252.259

[14] Chepngeno J, Owino W, Kinyuru J, Nenguwo N (2016) “Effect of Calcium Chloride and Hydrocooling on Postharvest Quality of Selected Vegetables" Journal of Food Research (vol. 5, no. 2, pp. 23-40) https://doi.org/10.5539/jfr. v5n2p23

[15] Senevirathna P, Daundasekera W a. M (2010) "Effect of postharvest calcium chloride vacuum infiltration on the shelf life and quality of tomato (cv. 'Thilina')" Ceylon Journal of Science (Biological Sciences) (vol. 39, no. 1, pp. 35-44) https://doi.org/10.4038/cjsbs.v39i1.2351

[16] Pinheiro SCF, Almeida DPF (2008) "Modulation of tomato pericarp firmness through $\mathrm{pH}$ and calcium: Implications for the texture of fresh-cut fruit" Postharvest Biology and Technology (vol. 47, no. 1, pp. 119-125) https://doi.org/ 10.1016/j.postharvbio.2007.06.002

[17] Wu T, Abbott JA (2002) "Firmness and force relaxation characteristics of tomatoes stored intact or as slices" Postharvest Biology and Technology (vol. 24, no. 1, pp. 59-68) https://doi.org/10.1016/S0925-5214(01)00133-8

[18] Moneruzzaman KM, Hossain ABMS, Sani W, Saifuddin M, Alenazi M (2009) "Effect of harvesting and storage conditions on the post harvest quality of tomato (Lycopersicon esculentum Mill) cv. Roma VF" Australian Journal of Crop Science (vol. 3, no. 2, pp. 113-121) 